\title{
LINGVISTINIAI IR KULTÜRINIAI LIETUVIŲ KALBOS RAŠYBOS KODIFIKACIJOS PRADŽIOS ASPEKTAI
}

\section{The Beggining of the Codification of Lithuanian Language Norms: The Linguistic and Cultural Issues}

\section{SUMMARY}

In 1905-1939, due to various historical, political and social factors, there were formed the norms for standard Lithuanian (1905-1918) and the dissemination of functions (1919-1939). The authors of Lithuanian language textbooks for schools continued the work started by Petras Kriaušaitis in his "Lithuanian language grammar" at the beginning of the 20th centuryand in his Lithuanian language syllabuses (syllabi), which influenced the textbooks. Therefore, the functions of the standard language were improved. School had a positive impact on the dissemination of language norms. The article deals with the aspects of the change and the establishment of the written language norms of the first Lithuanian textbooks for primary schools in the first half of the 20th century. The article presents the cultural background that had an impact on the formation of the norms of the standard language. The changes in spelling found in different textbooks show that during that period, due to the deliberate efforts of linguists and other active public figures, the consolidation of the norms for standard Lithuanian and the improvement of functions came from cultural and social factors.

\section{SANTRAUKA}

1905-1939 m., veikiant įvairiems kultūriniams, politiniams ir socialiniams veiksniams, formavosi lietuvių bendrinès kalbos normos įtvirtinimo (1905-1918) ir funkcijų sklaidos (1919-1939) etapai. Mokyklinių lietuvių kalbos vadovèlių autoriai tęsė XX a. pradžioje Petro Kriaušaičio Lietuviškos kalbos gramatika pradètą darbą, buvo kuriamos lietuvių kalbos mokymo programos, dariusios įtaką vadovèliams: skatino juos tobulinti, todèl tobulejjo ir bendrinės kalbos funkcijos - mokykloje vyko įdiegtųjų normų sklaida. Straipsnyje aptariami pirmųjų XX a. pirmosios pusės lietuvių kalbos vadovėlių pradžios mokykloms rašybos 
normų kaitos ir įsitvirtinimo aspektai, aptariamos kultūrinės aplinkybės, lėmusios bendrinės kalbos normų formavimosi veiksnius. Kintanti vadovèlių rašyba rodo, kad tuo laikotarpiu sąmoningų kalbininkų ir kitų aktyvių visuomenės veikẻjų pastangomis vyko lietuvių bendrinės kalbos normų įtvirtinimas ir funkcijų sklaida (tobulinimas), susijusi su kultūriniais ir socialiniais veiksniais.

\section{IVADAS}

Bendrinè lietuvių kalba pradejo kurtis $\mathrm{XVI}$ a., atsiradus pirmiesiems spausdintiems raštams šia kalba. Lietuvių bendrinès kalbos formavimosi istorijai pritaikius Einaro Haugeno bendrinių kalbų raidos teoriją (Haugen 1972), galima teigti, kad laikotarpi iki XIX a. pabaigos, iki Aušros pasirodymo (1883), galima pavadinti rašomuju atmainų raidos etapu, kuris lietuvių kalbos atveju tęsėsi ilgai, iki galutinio tarmès pasirinkimo. Bendrinès lietuvių kalbos kodifikacijos pradžia siejama su Petro Kriaušaičio Lietuviškos kalbos gramatika (Avižonis, Jablonskis [Petras Kriaušaitis] 1901). Funkcijos buvo tobulinamos nuolatos, tačiau šis darbas ypač sustiprèjo sukūrus Lietuvos valstybę 1918 m., kai lietuvių kalba galëjo pradèti laisvai funkcionuoti mokyklose ir valstybiniame gyvenime. Funkciju prièmimas vyko beveik tuo pačiu metu, 1918-1940 m., kai bendrinès kalbos sklaida ir funkcijos pradèjo itin stiprèti.

XIX-XX a. sandūroje kilus tautiniam ir kultūriniam lietuvių judèjimui, lietuviu kalba, iš pradžių greta lenkų kalbos, tapo išsilavinusių žmonių viešojo bendravimo kalba. Ilgą laiką lietuvių ir lenkų kalbos gyvavo tarsi skirtingose viešojo gyvenimo plotmėse (Budvytis 2019: 23), lietuviu kalba nesiskverbe i lenkų kalbos vartojimo sritị ir nebuvo jai konkurentè. Tačiau tautinis judèjimas keitè situaciją: lietuviškai vis dažniau buvo kuriama grožinè, politinè, mokslo populiarinimo, religinè ir kitokia literatūra ${ }^{1}$. Spaudos lietuviškais rašmenimis draudimo panaikinimas $1904 \mathrm{~m}$. atvėré daug palankesnes sąlygas tautos visuomeniniam ugdymui, tautinès kultūros ir bendrinès kalbos kūrimui.

Paskutiniais XIX a. dešimtmečiais, pradejjus eiti nelegaliai lietuviškai spaudai, visuomenè, o tiksliau, labiau išsilavinusi jos dalis, èmé suvokti, kad tarminis pagrindas jau pasirinktas. Sąmoningas visuomenès suvokimas, kad ji turi tokią kalbą (kalbos atmainą), labai svarbus bendrinès kalbos atsiradimui fiksuoti, - teigia Jurgita Venckienè (2016: 5). Šio suvokimo irodymu tapo $1901 \mathrm{~m}$. gramatika.

1901 m. Tilžèje Petro Kriaušaičio slapyvardžiu išleista Lietuviškos kalbos gramatika buvo parašyta Aušroje ir Varpe vartotu kalbos variantu ir Mažojoje Lietuvoje leistų raštų kalbos pagrindu. Irena Smetonienè (2014) teigia, jog gali būti, kad Lietuvoje dar ilgai būtų tekę laukti praktinès gramatikos, jeigu ne Amerikos lietuviu paskelbtas gramatikos konkursas. Šiam konkursui Jonas Jablonskis kartu su Petru Avižoniu kiek perdirbo jau šiek tiek anksčiau Avižonio parašytą Lietuviška gramatikèle, kurios rankraštis buvo žinomas jau Varpo leidejjams, išsiuntė i konkursą ir ji laimejo (Smetonienè 2014). Už laimètus pinigus gramatika, pavadinta Lietuviškos kalbos gramatika. Rašytojams ir Skaitytojams Vadovélis, 1901 m. pagaliau buvo išleista Tilžèje, Otto v. Mauderodès spaustuveje. Jablonskis, nors gerokai perdirbo ir išplètė gramatika, autorystės nesisavino, ji 
pasirašyta Petro Kriaušaičio slapyvardžiu (Petras - Avižonio vardas, Kriaušaitis - vienas iš Jablonskio slapyvardžių). Taigi ši gramatika ir Seinuose išleista Lietuviu kalbos sintakse (1911) padèjo pagrindus tolesnei bendrinès kalbos raidai ir norminimui.

Anot Jono Palionio, Lietuviškos kalbos gramatika buvo „didžiai reikšminga dèl to, kad joje pirmą kartą lietuvių kalbos moksle buvo teisingai nušviestas literatūrinès kalbos ir tarmiu santykis, ittvirtinta XIX a. pabaigoje iškilusi i lietuvių literatūrinès kalbos pagrindą aukštaičių vakariečių (pietiečių) tarmè, kad joje buvo padèti tvirti pamatai visai tolimesnei lietuvių literatūrinès kalbos kūrybai bei normalizacijai" (Palionis 1957: 23). Ši gramatika galutinai itvirtino vakaru aukštaičių kauniškių tarmę kaip bendrinès kalbos pagrindą: anot Zigmo Zinkevičiaus, „XIX a. paskutiniais dešimtmečiais èmusios visuotinai įsigalèti vakarų aukštaičių pietiečių tarmès lytys buvo kodifikuotos 1901 m. Petro Kriaušaičio Lietuviškos kalbos gramatikoje, ir po jos pasirodymo tos lytys dar labiau isitvirtino bendrinès rašomosios kalbos normu sistemoje" (Zinkevičius 1993: 229). Vèliau buvo atliekami dalinès arba papildomosios kodifikacijos darbai, t. y. prasidejjo, Einaro Haugeno, Anthony Lodge'o, Ann Lesley ir Jameso Milroy'aus terminais, antrasis lietuvių bendrinès kalbos raidos laikotarpis, nes būtent išsprendus tarminio bendrinès kalbos pamato problemą pasibaigia pirmasis bendrinès kalbos formavimosi etapas (plačiau žr. Haugen 1972; Logde 1993: 25-27; Subačius 1998: 27; Buivydienè 2013; Buivydienè 2019). Be abejo, šiam kalbos formavimosi etapui būdingas kalbos normų ivvairavimas. Apie ši reiškini rašo minèti bendrinių kalbų tyrejai, apie tai kalba ir $1901 \mathrm{~m}$. gramatikos autoriai: „Yra rašytojų, kurie reikalauja, kad gramatikoje nebūtų svyrinėjimų, kad būtų pasakyta, kaip tikrai reikètų kalbèti ir rašyti. Mūsų rašomoji kalba dar teip neišdirbta, jos rašyba teip nevienoda, juog tvirti istatymai jai duoti tuo-tarpu yra labai sunku. Reikia visuomet minèti, kad ir kitu tautu gramatikose, nors jų raštenybė daug daugiaus išdirbta, yra nemaža visokių svyrinejjimu" (Avižonis, Jablonskis [Petras Kriaušaitis] 1901: 2). Be to, autoriai pabrèžia ir kalbininkų asmeninio požiūrio i̇ normos reiškinius svarbą: „Tokia gramatika, kurios įstatymai visiems ittiktų, tiesiog negalima tuo-tarpu parašyti“ (Avižonis, Jablonskis [Petras Kriaušaitis] 1901: 2).

Taip pat prakalboje gramatikos autoriai aiškino bendrinès kalbos (gramatikoje vartotas terminas rašomoji kalba) formavimo principus (ir pagrindinius kalbos vadovėlio parašymo principus): „kalbos istatymus ir ypatybes mokslas išveda iš žmonių kalbos" (Avižonis, Jablonskis [Petras Kriaušaitis] 1901: 1). Tai ypač svarbu, pasak autorių, lietuvių kalbai, nes

„mūsų rašytojai patys yra dažnai parėmę savo raštų kalbą ne ant žmonių kalbos, bet ant svetimų kalbų i̇statymü" (Avižonis, Jablonskis [Petras Kriaušaitis] 1901: 1). Be to, net ir remiantis žmoniu kalba, reikia atsirinkti, kas yra būdinga lietuvių kalbai, o kas atsiradę dèl svetimų kalbų itakos. Kitas svarbus dalykas - vienos tarmès pasirinkimas bendrinès kalbos pagrindu: "rašomosios kalbos tiesas visuomet igyja kokia norint viena tarmè, kitos tarmès priduoda jai tiktai savo geriausius mažmožius, tuos grūdelius, kurie rašomoje tarmèje dèl kokios-norint priežasties yra išnykę, nebevartojami“ (Avižonis, Jablonskis [Petras Kriaušaitis] 1901: 1). 
Taigi bendrinè kalba buvo įtvirtinta 1901 m. išèjusioje Lietuviškos kalbos gramatikoje. To meto lietuvių kalbos vadovèliu autoriams ir visai visuomenei ši gramatika atrodè autoritetinga, ja imta remtis.

Susikūrus Lietuvos Respublikai, bendrinès kalbos kūrimo ir įtvirtinimo procesas tęsèsi. Svarbų normų ìtvirtinimo vaidmeni atliko Jablonskio Lietuviu kalbos gramatika (1922), Lietuviu kalbos vadovelis (1925) ir Linksniai ir prielinksniai (1928) leidiniai, standartizuojantys kalbos sistemą. 1922 m. Švietimo ministerija Jablonskio gramatiką patvirtino kaip privalomą visoms Lietuvos mokykloms. Taigi remtis Jablonskio gramatikomis tapo privaloma.

Dar vienas veiksnys, paskatinęs kokybinę lietuviu kalbos vadovèlių raidą, buvo pirmosios lietuviu kalbos mokymo programos (apie programas plačiau žr. Buivydienė 2011; 2013). XX a. pradžioje, oficialiai leidus dèstyti lietuvių kalbą kaip mokomajji dalyką pradžios ir pagrindinèse mokyklose, vadovèliu autoriai galejo

\section{NORMOS ITVIRTINIMO}

XX a. pradžios elementoriai ir gramatikos jau buvo rašomi daugiau ar mažiau mums ipprasta bendrine kalba, kuri, pasak Zinkevičiaus, pamažu įsigalèjo nuo laikraščio Aušra (Zinkevičius 2000: 102; Venckienė 2007: 139) ir $1901 \mathrm{~m}$. Lietuviškos kalbos gramatikos pasirodymo. Taigi nuo tada ir lietuviu kalbos vadovèliai pradèti rašyti kalba, kuri vèliau imta vadinti bendrines lietuviu kalbos terminu, juose buvo diegiamos iš pradžiu rašytinès kalbos, o vèliau ir bendrinès kalbos normos.

Nuo pirmuju XX a. pradžios mokymo programų buvo pradèta diegti rašomosios kalbos samprata. Keitėsi vadovèliu remtis minėta Jablonskio gramatika, bet dar reikejjo mokymo programų. Pasirodžiusios programos (1906 m. pirmasis lietuviu kalbos programos projektas (Programa 1906) ir $1909 \mathrm{~m}$. oficialiai patvirtinta programa (Programa 1909) padejo pamatus lietuvių kalbos mokymui ir mokymo sistemai. Daugiausia dèmesio programų autoriai kreipè į rašyba $i$ tai atsižvelgè ir vadovèliu, parašytų remiantis šiomis programomis, autoriai.

1915-1939 m. lietuviu kalbos mokymo programos buvo kuriamos toliau (Buivydienè 2013). Jose buvo akcentuojamos gramatikos temos, ị kurias įejo ir rašybos mokymas, pateiktas per šešerius pradinès mokyklos metus (Buivyienè 2013: 83). Palyginus su pirmosiomis mokymo programomis, akivaizdu, kad rašybos mokymui naujosiose progamose buvo skiriama dar daugiau temu ir mokymo laiko. Tai nulèmè ir naujų lietuvių kalbos mokymo vadovèliu, kurie būtu parašyti remiantis naujomis mokymo programomis, poreikì. kalba: rašyba, leksika, morfologija, sintaksė (plg. Damijonaičio gramatikų i̇vadinio autoriaus žodžio kalbą (žr. lentelę)).

$X X$ a. pradžioje dauguma elementorių ir gramatikų autoriu jau vartojo tradicini lietuvišką raidyną (Višinskis 1905; Damijonaitis [Domijonaitis] 1906 ir kt.), išskyrus kelis atvejus, pavyzdžiui, dvibalsis uo

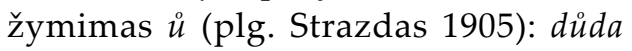
'duoda', šlůja ‘šluoja' (Strazdas 1905: 13). Jau buvo vartojamos raidès $\breve{c}, \breve{s}, v, l$ vietoj $c z, s z, w, l$, tačiau dauguma autoriu (Strazdas 1905; Višinskis 1905; Damijonaitis [Domijonaitis] 1905 ir kt.) nurodo, kad senesniuose raštuose pasitaiko ir 
Lentelè. Juozo Damijonaičio gramatikų kalbos pavyzdžiai

\begin{tabular}{|l|l|}
\hline \multicolumn{1}{|c|}{ Šaltinis } & \multicolumn{1}{|c|}{ Pavyzdys } \\
\hline Damijonaitis [Domijonaitis] 1909 & $\begin{array}{l}\text { Skaitau už reikalinga pažymėti, jog ši vadovéli taisiau } \\
\text { prisilaikydamas plačiai žinomos p. Petro Kriaušačio gra- } \\
\text { matikos (p. 2) }\end{array}$ \\
\hline Damijonaitis 1923 & $\begin{array}{l}\text { Turiu pažymèti, jog rašydamas ši trumpa gramatikos va- } \\
\text { dovéli mokslo pradžiai, naudojausi Rygiškiu Jono lietuviu } \\
\text { kalbos gramatika, sintakse ir kitais jo raštais (p. 2) }\end{array}$ \\
\hline
\end{tabular}

lenkiškos rašybos atvejų. Taigi lietuviško raidyno normos, galima sakyti, galutinai buvo iddiegtos pirmajame $X X$ a. dešimtmetyje. Nuo $1905 \mathrm{~m}$. šio raidyno buvo mokomi mokiniai.

Rašybos normos ìvairavo gerokai ilgiau. Tačiau rašybos mokymo svarba ryškejjo nuo pirmosios programos, kurioje rašybai buvo skirta 23 proc. programos temų (Buivydienè 2011; 2013). $1909 \mathrm{~m}$. programoje rašybai buvo skirta 26 proc. temu - labai panašiai kaip ir pirmojoje (plg.: dar 4 proc. - skyrybai; pirmojoje programoje skyrybos temu nebuvo, plačiau - Buivydienè 2013).

Daugelio 1905-1917 m. autoriu vadovèliuose priebalsiai rašomi kilminiu pagrindu, pavyzdžiui, augštas 'aukštas' (Vanagèlis 1909), Augšti 'aukšti' (Murka 1917: 10), kai kuriu - pagal fonetika, pavyzdžiui, gazdinti 'gąsdinti' (Višinskis 1905: 5); varkšas 'vargšas' (Bendorius 1905: 13); staptelti 'stabtelti' (Damijonaitis [Domijonaitis] 1906: 2); sezzdamasis 'sėsdamasis' (Jakučionis 1916: 2). Kilminiu pagrindu priebalsiai buvo rašomi dar ilgai, plg. rūkščios 'rūgščios' (Lazauskas 1938: 25).

Ivairuoja $i$ ir $y, u$ ir $\bar{u}$ rašyba: kniga 'knyga' (Strazdas 1905: 3), figura 'figūra' (Damijonaitis [Domijonaitis] 1905); kalakūtas 'kalakutas' (Damijonaitis [Domijonaitis]1906: 70) ir kalakutas (Skabeika 1909: 69); dūkrele 'dukrele' (Murka 1917:
7) ir kt. Dar kai kuriuose 1905-1916 m. laikotarpio elementoriuose rašyta mokisi 'mokysi' (Strazdas 1905: 3), tačiau Višinskio elementoriuje tais pačiais metais jau rašoma mokyti (Višinskis 1905); avis 'avys' (Vanagèlis 1909), musu 'mūsų' (Jakučionis 1916), rašyta męs ir jų (Bendorius 1905: 14); tris 'trys' (Bendorius 1905) ir pan. Nuo $1916 \mathrm{~m}$. jau rašoma mūsu (Jakučionis 1916: 63), jūs (Murka 1917: 64).

Priebalsio $j$ rašyba nenusistovejusi buvo ilgai: nusideimas 'nusidejjimas' (Strazdas 1905: 6); jieškotu 'ieškotu' (Višinskis 1905: 5); Jieva 'Ieva' (Strazdas 1905); Jievute 'Ievutè' (Bendorius 1905: 14); rugiapiūtè 'rugiapjūtè' (Vanagèlis 1909: 71); Rugpiūtis 'rugpjūtis' (Damijonaitis [Domijonaitis] 1906: 88; Jakučionis 1916: 62). Tik 1938 m. Lazausko vadovèlyje jau aiškiai apibrěžta $j$ rašyba: Reikia nepamiršti tokiu žodžiu, kur ie yra pradžioje: ieva (medis), Ieva (vardas), ienos, iešmas, ieškoti ir kt. Betgi: jie, jiems. Be to: jëga, pajëga, pajëgus, Jézus, jëzuitai (Lazauskas 1938: 19). Pateiktas ir įsidèmètinos rašybos žodžių sąrašas: Isidèmètini žodžiai: biaurus, piauti, spiauti, piaulai, piūklas, pabiuro ir t. t. (Lazauskas 1938: 24).

İvairių dalelyčių ar sudètinių įvardžių samplaikos gana nuosekliai rašytos su brūkšneliu: kai-kas, kai-katras (Skabeika 1909); iš-po (Bendorius 1905: 19); kai-kuriuose (Vanagèlis 1909: 117); šiek-tiek (Do- 
mijonaitis 1906: 2); maž-daug 'maždaug' (Skabeika 1909) - XIX a. pab.-XX a. pr. toks rašybos būdas buvo dažniausias, taip rašè Jablonskis $1901 \mathrm{~m}$. gramatikoje (Palionis 1995: 242). 1938 m. jau buvo rašoma maždaug (Lazauskas 1938: 11), tačiau gal būt (Lazauskas 1938: 3), tur būt (Lazauskas 1938: 50), kur-ne-kur (Lazauskas 1938: 24).

Pirmuosiuose pradžiamoksliuose buvo nenusistovëjęs žodžių (sutrumpejjusių žodžių, dalelyčių ir kt., ypač proklitinių ir enklitinių žodžių) rašymas drauge ir skyrium: plg. dèlko 'dèl ko' (Strazdas 1905); tur būt 'turbūt' (Višinskis 1905: 4); ikišiol 'iki šiol' (Višinskis 1905: 3); ir gi 'irgi' (Višinskis 1905: 4); taippat 'taip pat' (Damijonaitis [Domijonaitis] 1906: 1); persunkus 'per sunkus' (Malinauskas, Talmantas 1931: 63).

Prieveiksmiai su įvardžiu kuo rašyti kartu: Reikia žiūrèti, kad garsai būtu ištariami kuoaiškiausiai ir kuogryniausiai (Skabeika 1909: 1). Nuo 1920 m. pradedama rašyti abècèle (Damijonaitis 1920: 3), bet vis dar buvo rašoma todel, kodel (Malinauskas, Talmantas 1931: 56). 1938 m. Lazausko vadovėlyje jau rašoma kuo trumpiausiai (Lazauskas 1938: 18).

Iki 1916 m. mènesių pavadinimai rašyti didžiosiomis raidèmis, plg. Rugsèjis, Spaliu mènuo, Lapkritys ir Gruodis (Damijonaitis [Domijonaitis] 1906: 81). Jakučionis mènesiu pavadinimus jau rašè mažosiomis raidèmis: rugpiūtis, spaliai, lapkritys (Jakučionis 1916: 62).
Nuo 1915 m. vadovèliuose rašyba jau labiau nusistovejjusi, ypač nuo 1922 m. Jablonskio gramatikos pasirodymo, nes šioje gramatikoje kodifikuota rašyba buvo vartojama mokykliniuose vadovèliuose be didesnių pakitimų iki pat Antrojo pasaulinio karo.

Pradžios mokyklos gramatikose, ypač Nepriklausomos Lietuvos laikotarpio, rašybai skiriama daug dėmesio: pavyzdžiui, Murka Mažojo lietuviu kalbos vadovélio antrosios dalies (1925) pabaigoje teikia rašybai kartoti skirtą Priedèli (Murka 1925: 192), be to, rašybos taisyklès ir itvirtinimo pratimai siejami su kalbos dalių mokymu, todèl rašybos taisykliu mokoma visuose pradžios mokyklos skyriuose. 1919 m. programoje rašybos temos pateikiamos kartu su morfologijos ir kalbos dalių temomis, todèl jos mokoma visus ketverius metus, o patvirtinus šešerių metų pradinị mokymą - rašybos mokoma šešerius metus.

Lazausko vadovèlyje išsamiau mokoma didžiųjų raidžių rašybos. Imonių ir îstaigu pavadinimų visi žodžiai rašomi didžiosiomis raidèmis: Švietimo Ministerija, Vytauto Didžiojo Universitetas (Lazauskas 1938: 15). Kai kuriais atvejais teikiami keli galimi atvejai: Žodžius Baublys (Poškos), Puntukas visi rašo didžiaja raide. Gyvuliu vardus paprastai rašo mažaja raide: margius, rainys, širmis ir $t$. $t$.; bet daug kas rašo ir didžiaja raide: Margius, Rainiukas, Brisius ir t. t. (Lazauskas 1938: 16) - nèra vienos griežtos normos.

\section{APIBENDRINIMAS}

Galima teigti, kad 1905-1939 m. formavosi lietuvių bendrinès kalbos normos itvirtinimo (1905-1918) ir funkcijų sklai- dos (1919-1939) etapai. Jų ribas tiksliai nustatyti sudètinga, nes kai kurie reiškiniai būdingi abiem etapams. Mokykliniai 
lietuvių kalbos vadovèliai tęsė $X X$ a. pradžioje Petro Kriaušaičio Lietuviškos kalbos gramatikos pradètą darba, todèl tobulejo bendrinès kalbos funkcijos - mokykloje vyko įdiegtujjų normų sklaida ir jų prièmimas, kuris labai svarbus bendrinès kalbos formavimuisi ir isitvirtinimui. Tuo laiko- tarpiu sąmoningai kuriama bendrinè lietuvių kalba turejjo suartinti įvairiatarmius ir net ivvairiakalbius Lietuvos gyventojus, užtikrinti viešojo bendravimo aiškuma, padèti ugdyti lietuvišką raštiją, kurti moksla, švietimą ir mena, vadinasi, atliko ir svarbų kultūrą formuojamajị vaidmenį.

\section{IŠVADOS}

1. Straipsnyje apžvelgti 1905-1940 m. lietuvių kalbos vadovèlių pradžios mokykloms rašybos aspektai atspindi to laikotarpio besiformuojančios lietuviu bendrinès kalbos rašybos raidą.

2. 1905-1940 m. laikotarpiu buvo sąmoningai projektuojama lietuviu bendrinè kalba, susijusi su kultūrine ir tautine Lietuvos valstybès ir kalbos samprata, kuri, esant didžiulei tarminei ivvairovei, atrodè svarbiausia siekiamybè. Variantiškumas buvo vertinamas neigiamai, kaip komunikacijos trukdis, tačiau buvo suvokiama, kad visiškai to išvengti neįmanoma.

3. Normos įtvirtinimo vaidmenį atliko 1905-1909 m. vadovèliai, kurie rèmėsi Petro Avižonio slapyvardžiu pasirašyta pirmajja gramatika ir pirmosiomis mokymo

\section{Literatūra}

Avižonis Petras, Jablonskis Jonas [Petras Kriaušaitis]. 1901. Lietuviškos kalbos gramatika. Rašytojams ir skaitytojams vadovélis. Tilžè: spauzdinta pas Otto v. Mauderode.

Bendorius Petras 1905. Vaiku žvaigždutè. Knygelè I ir II mokyklos skyriui ir vaikams pramokusiems skaityti (Pasiskaitymai ir pirmutinès gramatikos žinios). Vilnius: Juozapo Zavadskio spaustuvè.

Budvytis Jonas. 2019. Jonas Basanavičius. Gyvenimas ir veikla Vilniuje 1905 rugpjūtis - 1907 metų kovas. Vilnius: Lietuvos nacionalinis muziejus.

Buivydienė Vaida. 2011. Lietuvių kalbos mokymas XX a. pradžioje: pirmosios lietuvių kalbos mo- programomis. 1905-1940 m. vadovèliu kalba rodo jau susiformavusį neivaairuojantį raidyna, tačiau įvairuojančią rašybą.

4. Funkciju sklaidos (tobulinimo) vaidmeni atliko 1915-1940 m. mokymo programos ir vadovèliai. 1915-1940 m. vadovèliuose mažiau ivvairuoja rašyba, gramatikos temoms skiriama daugiausia dèmesio, tačiau gramatika suvokiama daugiausia kaip rašybos mokymas. Rašybos temos plètojamos per šešerius pradžios mokyklos metus.

5. Vadovèliu rašybos normų raidos apžvalga atskleide, kad normų raidą ir kurio nors reiškinio pasirinkimą iš konkuruojančiu normos variantu nulėmé asmeniniai gramatikų ir vadovèliu autoriu pasirinkimai ir kultūrinių bei socialiniu aplinkybių nulemti veiksniai.

kymo programos ir to laikotarpio vadovèliai. Naujausi kalbu ir kultūru tyrimai. Kalbu ir kultūru sankirtu archyvai 4: 183-223.Vilnius: Europos kalbų ir kultūrų dialogo tyrëjų asociacija; UAB "Petro ofsetas".

Buivydienè Vaida. 2013. XX amžiaus pirmosios pusès pradžios mokyklu gimtosios kalbos vadovèliu turinio ir kalbos norminimo bruožai. Daktaro disertacija. Vilnius.

Buivydienè Vaida. 2019. Vèlyvo bendrinès kalbos su(si)kūrimo sociokultūrinès aplinkybès: lietuvių bendrinès kalbos atvejis. Logos 100: 190197. 
Damijonaitis [Domijonaitis] Juozas. 1906. Rašymo ir skaitymo pradžiamokslis. Varšuva: Saturn.

Damijonaitis Juozas. 1909. Trumpa lietuviu kalbos gramatika. Vilnius: Juozapo Zavadskio spaustuvè.

Damijonaitis Juozas. 1923. Lietuviu kalbos gramatika. Trumpas vadovelis mokykloms (mokslo pradžiai). Marijampolè: „Dirvos“ bendrovès spaustuvè.

Haugen Einar. 1972. The Ecology of Language. Essays by Einar Haugen. Selected by Anwar S. Dil. California: Stanford University Press.

Jakučionis Augustinas. 1916. Kelias i šviesa kelias $i$ skaitymo ir rašymo mokyma. Vilnius: Juozapo Zavadskio spaustuvè.

Lazauskas Juozas. 1938. Lietuviu kalbos gramatika V ir VI pradžios mokyklos skyriui. Kaunas: Spaudos fondas.

Logde R. Anthony. 1993. French: from dialect to Standard. London and New York: Rouledge.

Malinauskas Ignas, Talmantas Jonas. 1931. Lietuviu kalbos gramatika pratimais. II-ajam pradžios mokyklos skyriui. Kaunas: šv. Kaziemiero dr-jos leidinys.

Milroy James, Milroy Lesley. 1999. The Authority of Language. Investigating Standard English. 3ed edition. London and New York: Routledge.

Murka Jonas. 1917. Lietuviu kalbos vadovélis: iž̌engiamoji dalis. Petrapilis: Lietuvių spaustuvè.

Murka Jonas. 1925. Mažasis lietuviu kalbos vadovélis: 2-ajam pr. m-klos sk. Kaunas: Švyturio bendrovès spaustuvè.

Palionis Jonas. 1957. J. Jablonskis ir jo lietuvių kalbos vadovėliai. J. Jablonskis. Rinktiniai raštai 1 : 5-54. Vilnius: Valstybinè politinès ir mokslinès literatūros leidykla.

Palionis Jonas. 1995. Lietuviu rašomosios kalbos istorija. Vilnius: Mokslo ir encikopedijų leidykla.

Piročkinas Arnoldas. 1977. Prie bendrinès kalbos ištaku: J. Jablonskio gyvenimas ir darbai 1860-1904. Vilnius: Mokslas.

\section{Nuorodos}

1 Lenkų kalbos vartojimo sritis siaurèjo, šios dvi kalbos darèsi varžovèmis. Tai, pasak Vytauto Budvyčio (Budvytis 2019: 23), aštrino žmonių santykius; ypač ten, kur daugumai jų buvo trukdoma vartoti gimtąą kalbą. Bręstant moderniai lietuvių tautai, o daliai Lietuvos lenkakalbių gyventojų be išlygu issiliejant į modernią lenkų tauta, pasirinkimo kryžkeleje atsidūrè ir lenkakalbiai, ir lenkų kultūros paveikti iš lietuvių
Programa. 1906. Pavyzdinis lietuvių kalbos mokymo programas žemesnèms ir vidutinèms mokslo izstaigoms Vilniaus, Kauno, Gardino ir Suvalkų gub. Vilniaus žinios, 1906 m. gegužès 10 (23) d., Nr. 99 (417).

Programa. 1909. Lietuvių kalba žemesniosiose mokyklose ir lietuvių kalbos mokytojai. Mokykla 2.

Skabeika Klemensas. 1909. Kas skaito rašo - duonos neprašo. Vilnius: M. Kuktos spaustuvè.

Smetonienė Irena. 2014. Kalbos vieta valstybių politikoje: standartinių kalbų susikūrimas, Parlamento studijos. Mokslo darbai 16. Vilnius.

Strazdas Kazimieras. 1905. Naujas ir senas elementorius: mokitis labai lengvas. Vilnius: Vilniaus žinių spaustuvè.

Subačius Giedrius. 1998. Žemaičių bendrinès kalbos idejos. XIX amžiaus pradžia. Vilnius: Mokslo ir enciklopedijų leidybos institutas.

Subačius Giedrius. 2001. Written standard and spoken standard. Baltu filologija 10: 127-136.

Subačius Giedrius. 2004. Standartinių (bendrinių) kalbų istorijos, Metmenys 84: 97-115.

Vanagèlis [Ksaveras Sakalauskas]. 1909. Dovanèle. Skaitymo ir rašymo mokslas. Elementorius ir pirmoji knygele. Vilnius: Juozapo Zavadskio spaustuvè.

Venckienè Jurgita. 2007. Lietuviu bendrinès kalbos pradžia: idejjos ir ju sklaida (1883-1901). Daktaro disertacija. Vilnius.

Venckienė Jurgita. 2016. Lietuvių bendrinès kalbos sampratos istorija (XIX amžiaus antroji puse XX amžiaus pradžia). Bendrine kalba 89. Prieiga per internetą: http://www.bendrinekalba.lt/ Straipsniai/89/Venckiene_BK_89_straipsnis.pdf

Višinskis Povilas. 1905. Elementorius arba skaitymo ir rašymo mokslas. Vilnius: Juozapo Zavadskio spaustuvè.

Zinkevičius Zigmas. 1993. Rytu Lietuva praeityje ir dabar. Vilnius: Mokslo ir encikloedijų leidykla.

Zinkevičius Zigmas. 2000. Elementorių kalba. Lietuviški elementoriai: 95-98. Kaunas: Šviesa.

liaudies kilę gyventojai. Pavyzdžiui, Vincas Kudirka (1858-1899), kuris buvo vienas žymiausių lietuvių tautinio judejimo vadų, taip pat trys smulkieji bajorai broliai Biržiškos, iš kurių per 1897 m. surašymą du buvo užsirašę žemaičiais, o vienas lenku, brandos metais visi trys tapo žymiais Lietuvos valstybès kultūros ir polikos veikèjais (plačiau - Budvytis 2019). 